\section{Soff Words at Geneva}

To everybody's surprise, the long session of the UN Disarmament Subcommittee which closed last Friday at Geneva has turned out to be amiable as these things go. One symptom, or possibly a cause, has been the wide range of the discussions. Several topics which could yet become the kernels of arms control agreements have been raised. To be sure, the freedom of the discussions has not been matched by the signature of treaties. If there is a tangible outcome of this session's work, it will almost certainly be a treaty to demilitarize the sea bed. Heady talk of treaties to abolish chemical and biological weapons, in which the British Government has been prominent, have been fruitless for lack of preparation or, more charitably, because of the great difficulties of inspection and control. Other schemes, such as the comprehensive test-ban for which the Swedish Government pleaded eloquently on the closing day of the session, have been frustrated by the determination of the Great Powers to carry on as they are.

One of the most hopeful signs has been the reemergence of talk of a cessation of the production of fissile material for military purposes, for this is an essential ingredient in any scheme for making sure that there is some check on the nuclear powers to compensate for the restrictions which the Non-Proliferation Treaty applies to the lesser fry. One obstacle here, typified by the Russian reply to the American initiative, is that a cut-off agreement would not affect existing stockpiles of nuclear explosives; such imbalances as now exist may thus be perpetuated. But a cut-off agreement would also entail the kind of detailed inspection of military establishments which the Soviet Union has consistently resisted-except in the last unattainable stages of "General and Complete Disarmament". Yet the mere discussion of the cut-off proposals is a sign that things may be on the move.

Why should this be ? The promised talks between the Soviet Union and the United States on the limitation of strategic missiles are the most beneficent of several influences. Something should be known of progress in this direction before the next session begins on July 9. But there also seems to have been a slow if painful recognition among the Great Powers that the hard-won NPT may not win many adherents among the non-nuclear powers unless there is some reciprocal gesture by the Soviet Union and the United States. As luck will have it, this is why the missile talks could be critical in several ways. By contrast with the potential benefits of those discussions, the chance of an agreement about the deep sea bed, although not entirely insignificant, is not much to boast about.

Even here, however, agreement will not be easy.
Urged on by the other fifteen members of the subcommittee, the governments of the Soviet Union and the United States have produced separate drafts of a treaty. Optimists will point out the several common features in these proposals, chiefly the willingness of both parties to extend the treaty to all but a narrow coastal strip. Two serious obstacles remain. The Soviet Union would prohibit all military installations on the sea bed, but the United States would limit the prohibition to "weapons of mass destruction". The difficulty here is chiefly the American wish to retain or to create systems for detecting hostile submarines. There is also disagreement about degree of inspection which the two governments would allow-the Russians ask for the right of inspection by "mutual agreement" but the Americans would permit only "observation".

If precedent is any guide, the argument should lie with the United States draft, which is a close analogue of the treaty now in force on the banning of "weapons of mass destruction" in what is called outer space. There is also much to be said for the development of systems of submarine surveillance and no good reason why their existence should not be publicly advertised. So may there not be room for compromise on the American view of the scope of the prohibition and the Russian view of the degree of inspection which the treaty would allow ? That, at least, should be the hope, for a treaty along these lines would only be worth having if it were signed quickly. The objective should be to prevent the building of missile launching sites on the sea bed in the interval, possibly a long one, before there can be agreement on the limitation of strategic missiles. The Great Powers are undoubtedly well aware that sea bed missiles would be immune from aerial inspection and thus the preferred instruments of a second-strike nuclear force. Haggling would allow the horse to bolt before the stable door is shut. Whatever the niceties of diplomacy, this is a case for acting quickly or not at all.

\section{SPACE RESEARCH \\ Optimism in the Air}

Now that the European Space Research Organization is once again an established feature of the European scene, with the lifting by last November's European Space Conference of the ban on new projects, space users sound less like the Jonahs of last year. At a symposium in Paris earlier this month, ESRO presented feasibility studies on six spacecraft, ranging from the humdrum atmospheric satellite to a Mercury fly-by mission complete with television cameras, which will be the ingredients for a programme going well 
into the 1970s. Each of the objects would be launched either in 1974 or 1975 , following on the series of more conventional satellites already arranged for the period up to 1972. The intention seems to be to select one or even two of the projects in time for the next council meeting in July.

At the same time, the management of the European space effort is likely to be further simplified. Talks have been under way for some time on the merging of a large part of ELDO and ESRO, and there should be some news of progress by July. The outcome seems to be encouraging, although nobody is clear how British attitudes towards ELDO will be reconciled with declared interests in research and applications such as the CETS television satellite.

The ESRO report for 1968, just published, captures some of the enthusiasm which is beginning to be felt again. For the first time, there is also a section called "Satellites in Operation". The sounding rocket programme, so far the mainstay of ESRO research, continued at much the same level as before, with twenty launchings last year. For the first time, however, ESRO's launching facilities at Kiruna in Sweden were used by national groups-a welcome step towards the promised role of ESRO as a provider of facilities out of the reach of individual states. The report also shows that the recommendations of the Bannier report on working methods have been taken to heart. An extension of the powers of the Director-General (Professor Hermann Bondi) is the main change, and has much to do with the sudden upsurge in ESRO's fortunes. ESRO's pessimistic attitude in offering only shortterm contracts to its A-grade staff is likely to be changed, and there is talk of some kind of career structure once the future of ESRO in the European space agency is settled.

As usual, the report has a section on the distribution of contracts among member states-almost obligatory now for a European cooperative venture in science and technology - which this year uses a weighting technique depending on the supposed technological worth of the contracts to cloud the issue further. States such as Spain and Denmark still come off significantly worse than France and Belgium. The report lists the ratio of the percentage of contracts which each state received to the percentage of the ESRO budget which it contributes. The ratio is highest for France (1.927), and least for Denmark $(0 \cdot 301)$. The ratio for Britain is $0 \cdot 650$.

Of the six spacecraft now under discussion for the next phase of the programme, two are fairly standard ionosphere and atmosphere satellites. The other projects, likely to be looked on more favourably in ESRO's present mood, are an ultraviolet astronomy satellite, a cosmic ray satellite, the Mercury probe and a geostationary satellite to study the magnetosphere. The Mercury probe is the subject of a design study by Messerschmitt-Bölkow, and would have to be undertaken as a joint effort with NASA. As well as the television cameras, the payload includes a Mariner-like complement of photometers, polarimeters and radiometers to study the surface and atmosphere of the planet, as well as magnetometers and micrometeorite detectors to investigate the interplanetary medium up to 0.4 astronomical units from the Sun. So far, American and Russian planetary probes have reached only the adjacent planets Mars and Venus.

\section{NUCLEAR POWER}

\section{Club for the Well-10-do}

Атомг energy has done little for the developing countries so far. Less than two per cent of all atomic power stations either built or being built lie outside the charmed circle of advanced industrial nations. The chief reason for this is that at present nuclear power is only competitive with oil, coal and water when produced in plants too big for most developing countries. But other and cheaper nuclear techniques are not making the contribution that they might to developing economics, and the International Atomic Energy Agency has just issued a booklet lamenting the situation (Atomic Energy in the Developing Countries, IAEA, Vienna, 1969).

The IAEA's regular budget is \$11 million for 1969 , and the agency is hoping for a further $\$ 2$ million in voluntary contributions from its member states. Voluntary contributions do not always turn up, however, and the IAEA managed to earn only $\$ 1 \cdot 3$ million in this way in 1968. The funds avajlable to the agency's own technical assistance programme have been shrinking, both in real terms and in relation to demand, for several years; in the early days, nearly every reasonable request for technical assistance could be met, but now the proportion is one in four.

This is why the IAEA is having to concentrate on inexpensive pioneering projects, hoping to seed the ground in preparation for larger ventures financed by the UN Development Programme. The fastest growing sector of the agency's activities has recently been the use of isotopes in agriculture. A plant breeding programme was set up jointly with the FAO in 1964 , and the scientists engaged in this programme have obtained valuable mutants of rice and wheat by gamma irradiation. One rice strain has a doubled protein content, while two mutant strains of wheat have just been released to farmers in Italy after four years of FAO-IAEA trials. Isotopes are also finding a use in studies of fertilizer use, insect control, food preservation and the tracing of insecticide residues.

But IAEA is well aware that in the long term the greatest impact of nuclear science will be its provision of cheap and limitless electric power. The agency has sent advisory missions to Brazil, Greece, Kuwait, Korea and Yugoslavia to help plan nuclear power programmes. Other countries have been helped in framing legislation on nuclear safety. Argentina and India are now committed to nuclear programmes, while Brazil and Greece will probably take their first steps soon. Cheap power will make large desalination plants possible, and the planning of a joint Mexico-United States-IAEA plant, capable of producing 1,000 million gallons of fresh water a day, is partly complete.

\section{CONCORDE \\ The Sky is not the limit}

The British and French Governments have at last come clean and admitted that the estimated cost of Concorde has increased by more than 50 per cent since 1966. Mr A. Wedgwood Benn, the Minister of Technology, announced at question time in the House of Commons on May 21 that the current estimate, agreed 